\title{
PENGARUH KINERJA KEUANGAN DAN CORPORATE SOCIAL RESPONSIBILITY TERHADAP NILAI PERUSAHAAN PADA PERUSAHAAN SEKTOR PERBANKAN YANG TERDAFTAR DI BURSA EFEK INDONESIA (BEI) PERIODE 2014-2015
}

\author{
Rosa Lia Warti \\ Rossaliaabdillah@gmail.com \\ Jurusan Manajemen \\ SEKOLAH TINGGI ILMU EKONOMI “KEUANGAN, PERBANKAN DAN \\ PEMBANGUNAN" PADANG. \\ 2017
}

\begin{abstract}
This research as a purpose to know what influence of financial performance and corporate social responsibility (CSR) on the firm value. Sample from this research is thirty two banking companies in Indonesian Stock Exchange period 2014-2015. The data analysis technique used multiple linear regression analysis using Eviews. The independent variables are corporate performance (Return On Assets, Return on Equity, Operating Profit Margin, and Net profit Margin), and Corporate Responsibility Social, while the dependent variable is the firm value (Price Book Value). From the result of tests performed showed that ROA, ROE, OPM, and CSR not significant affect on firm value. Be different with NPM who were statistically significantly firm value.
\end{abstract}

Keywords : firm value, ROA, ROE, OPM, NPM, corporate social responsibility

\section{PENDAHULUAN}

Perbankan Indonesia saat ini mengalami beberapa masalah serius, baik itu dalam masalah ketidak pastian pasar keuangan dunia, maupun penurunan ekspektasi kinerja keuangan. Perbankan mengalami tekanan dari faktor pelemahan ekonomi global maupun domestik, seperti pertumbuhan ekonomi, harga komoditas anjlok dan kurs rupiah yang berdampak pada sektor keuangan, untuk mengatasi masalah pasar keuangan dunia, maka diharapkan pertumbuhan dana tahun ini akan dapat membaik dari tahun-tahun sebelumnya, ini dilakukan untuk mencari strategi membangun funding tepat dan benar karena pertumbuhan dana merupakan salah satu sumber utama pertumbuhan kredit. Sedangkan penurunan ekspektasi kinerja keuangan disebabkan oleh beberapa factor, seperti kredit bermasalah yang meningkat, pelemahan nilai rupiah dan risiko likuiditas, namun meskipun begitu secara umum kinerja keuangan bank masih menunjukkan pertumbuhan positif dan masih stabil dan diharapkan masih akan terus membaik.

Sehatnya suatu perusahaan perbankan dapat dinilai dari harga saham dan Besar kecilnya nilai suatu perusahaan perbankan tersebut. Nilai perusahaan adalah 
asset perusahaan yang sesungguhnya. Nilai perusahaan yang optimal merupakan tujuan utama dari suatu perbankan dalam jangka panjang. Nilai perusahaan sangat penting karena dengan nilai perusahaan yang tinggi akan diikuti oleh tingginya kemakmuran pemegang saham (Bringham dan Houston,2006: 19), Semakin tinggi harga saham semakin tinggi pula nilai perusahaan. Jadi dengan tingginya nilai perusahaan suatu perbankan maka kemakmuran para pemegang sahamnya akan dapat dipertanggung jawabkan.

Nilai perusahaan menggambarkan seberapa baik atau buruk manajemen mengelola kekayaannya, hal ini bisa dilihat dari pengukuran kinerja keuangan yang diperoleh. Suatu perusahaan akan berusaha untuk memaksimalkan nilai perusahaannya. Peningkatan nilai perusahaan biasanya ditandai dengan naiknya harga saham di pasar (Rahayu, 2010). Ada beberapa rasio yang dapat digunakan untuk mengukur nilai pasar perusahaan, salah satunya adalah Price to Book Value. Menurut Hermawati (2010) Price to Book Value (PBV) adalah angka rasio yang menjelaskan seberapa kali seorang investor bersedia membayar sebuah saham untuk setiap nilai buku per sahamnya. PBV diperoleh dengan cara perbandingan nilai pasar yang diukur dengan harga saham penutupan, terhadap nilai buku (book value) memberikan penilaian akhir dan mungkin yang paling menyeluruh atas status pasar saham perusahaan.

Menurut Zuredah

pengukuran kinerja keuangan merupakan salah satu faktor yang sangat penting bagi perusahaan, karena pengukuran tersebut digunakan sebagai dasar untuk menyusun sistem imbalan dalam perusahaan. Menurut (Rahayu, 2010) Penilaian prestasi suatu perusahaan dapat dilihat dari kemampuan perusahaan itu menghasilkan laba. Untuk mengukur kinerja keuangan perusahaan biasanya menggunakkan analisis rasio keuangan (Hadya, 2013; Suhartono \& Yusra, 2019; Yusra, 2016; Yusra, Hadya, \& Fernandes, 2017). Rasio-rasio itu antara lain Return On Asset (ROA), Return On Equity (ROE), Operating Profit Margin (OPM), dan Net Profit Margin (NPM).

Pada saat ini CSR telah menjadi fenomena global dan telah dikonferensikan yang bertujuan untuk memperbaiki praktik bisnis dengan memperhatikan lingkungan hidup dan aspek sosial baik didalam maupun diluar perusahaan. Pengukuran kinerja CSR adalah melalui laporan kegiatannya, yakni dengan metode content analysis yang merupakan suatu cara pemberian skor pada pengukuran pengungkapan sosial laporan tahunan yang dilakukan dengan pengamatan mengenai ada tidaknya suatu item informasi yang ditentukan dalam laporan tahunan, apabila item informasi tidak ada dalam laporan tahunan maka diberi skor 0 , dan jika item informasi yang ditentukan ada dalam laporan tahunan maka diberi skor 1 .

Beberapa tahun terakhir banyak perusahaan semakin menyadari pentingnya menerapkan program Corporate Social Responsibility (CSR) sebagai bagian dari strategi bisnisnya. Penelitian Bassamalah dan Jermias (2005) 
menunjukkan bahwa salah satu alasan manajemen melakukan pelaporan sosial adalah untuk alasan strategis. Meskipun belum bersifat mandatory, tetapi dapat dikatakan bahwa hampir semua perusahaan yang terdaftar di Bursa Efek Indonesia sudah mengungkapkan informasi mengenai CSR dalam laporan tahunannya.

Berdasarkan latar belakang di atas, maka peneliti tertarik untuk meneliti tentang Pengaruh Kinerja Keuangan Dan Corporate Social Responsibility Terhadap Nilai Perusahaan Pada Perusahaan Sektor Perbankan Yang Terdaftar Di Bursa Efek Indonesia (Bei) Periode 2014-2015

\section{Rumusan Masalah}

1. apakah ada pengaruh kinerja keuangan terhadap nilai perusahaan sektor perbankan yang go public di Bursa Efek Indonesia?

2. apakah ada pengaruh Corporate Social Responsibility (CSR) terhadap nilai perusahaan sektor perbankan yang go public di Bursa Efek Indonesia?

\section{Tujuan Penelitian}

1. Untuk menguji pengaruh kinerja keuangan terhadap nilai perusahaan sektor perbankan yang go public di Bursa Efek Indonesia.

2. Untuk menguji pengaruh Corporate

Social Responsibility

(CSR) terhadap nilai perusahaan sektor perbankan yang go public di Bursa Efek Indonesia.

\section{LANDASAN TEORI DAN HIPOTESIS}

\section{A. Nilai Perusahaan}

Nilai perusahaan dalam penelitian ini didefinisikan sebagai nilai pasar, seperti halnya penelitian yang pernah dilakukan oleh (Nurlela dan Islahuddin, 2008), karena nilai perusahaan dapat memberikan kemakmuran pemegang saham secara maksimum apabila harga saham perusahaan meningkat.Semakin tinggi harga saham, maka makin tinggi kemakmuran pemegang saham.

\section{B. Kinerja Keuangan}

Menurut Chandra (2010) kinerja keuangan merupakan prestasi kerja yang telah dicapai oleh perusahaan dalam suatu periode tertentu dan tertuang pada laporan keuangan perusahaan yang bersangkutan. Analisis rasio keuangan merupakan instrumen analisis prestasi perusahaan yang menjelaskan berbagai hubungan dan indikator keuangan yang ditujukan untuk menunjukkan perubahan dalam kondisi keuangan atau prestasi operasi di masa lalu.

Makna dan kegunaan rasio keuangan dalam praktik bisnis pada kenyataannya bersifat subyektif, bergantung pada untuk apa suatu analisis dilakukan dalam konteks apa analisis tersebut diaplikasikan. Dalam pengukuran kinerja keuangan suatu perusahaan terdapat berbagai macam rasio yang digunakan. Dalam penelitian ini digunakan rasio Return on Assets (ROA), Return on Equity (ROE), OperatingProfit Margin (OPM), Net Profit Margin (NPM) sebagai analisa utama penilaian kinerja. 


\section{Corporate Social Responsibility \\ Corporate social responsibility}

(CSR) atau pertanggung-jawaban sosial perusahaan adalah mekanisme bagi suatu organisasi untuk secara sukarela mengintegrasikan perhatian terhadap lingkungan dan sosial ke dalam operasinya dan interaksinya dengan stakeholders, yang melebihi tanggung jawab organisasi di bidang hukum (Darwin, 2004 dalam Kusumadilaga, 2010).Corporate social responsibility merupakan komitmen perusahaan atau dunia bisnis untuk kontribusi dalam pembangunan ekonomi yang berkelanjutan dengan menitik beratkan pada keseimbangan antara perhatian terhadap aspek ekonomi, sosial, dan lingkungan.

\section{Kerangka Konseptual}

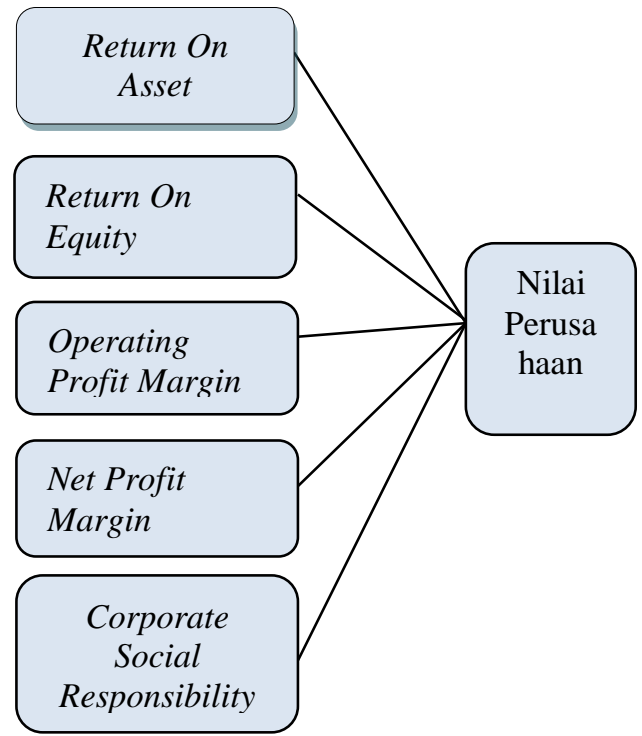

Gambar 2.1

Kerangka konseptual

\section{Hipotesis Penelitian}

H1 :Return On Asset (ROA) berpengaruh signifikan terhadap nilai perusahaan perbankan yang terdaftar di Bursa fek Indonesia.

$\mathrm{H} 2$ :Return On Equity (ROE) berpengaruh signifikan terhadap nilai perusahaan perbankan yang terdaftar di Bursa fek Indonesia.

H3 :Operating Profit Margin (OPM) berpengaruh signifikan terhadap nilai perusahaan perbankan yang terdaftar di Bursa fek Indonesia.

H4 :Net Profit Margin (NPM) berpengaruh signifikan terhadap nilai perusahaan perbankan yang terdaftar di Bursa fek Indonesia.

H5 :Corporate Social Responsibility (CSR) berpengaruh terhadap nilai perusahaan perbankan yang terdaftar di Bursa efek Indonesia.

\section{METODE PENELITIAN}

\section{Jenis Penelitian}

Jenis penelitian yang ada dalam penelitian ini adalah penelitian kuantitatif. Penelitian kuantitatif merupakan data penelitian yang berbentuk angka atau data kualitatif yang diangkakan atau scoring (Sugiono, 2008).

\section{Jenis dan sumber data}

Jenis data yang digunakkan dalam penelitian ini adalah berupa data sekunder yaitu data yang diambil dari catatan atau sumber lain yang telah ada sebelumnya. Ada 2 jenis data yang digunakan dalam penelitian ini, yaitu data kualitatif dan data kuantitatif. Data kualitatif diambil dari buku, jurnal, skripsi, penelitian terdahulu, dan situs internet yang berhubungan dengan tema penelitian ini. Sedangkan data 
kuantitatif berupa data angka-angka yang terdapat pada laporan tahunan (annual report) bank go public yang diperoleh dari situs resmi masingmasing bank dan situs Bursa Efek Indonesia (BEI).

\section{Teknik pengumpulan data}

Metode pengumpulan data yang digunakan dalam penelitian ini adalah studi dokumentasi, yaitu metode pengumpulan data yang dilakukan dengan mengumpulkan seluruh data sekunder yang terdapat didalam laporan keuangan dan annual report perusahaan dan seluruh informasi melalui jurnaljurnal, buku-buku, dan media informasi lainnya.

\section{Definisi Operasional Variabel}

\section{a. Nilai Perusahaan (Y)}

Variabel terikat yang digunakan dalam penelitian ini adalah nilai perusahaan yang diukur menggunakan Price to Book Value (PBV). Rumus yang digunakan dalam penelitian ini sebagai berikut :

$$
\begin{gathered}
P B V=\frac{\text { harga saham }}{\text { nilai buku saham }} \\
B V=\frac{\text { harga saham }}{\text { saham beredar }(S B)}
\end{gathered}
$$

b. Return on Assets (X1)

Menurut Dendawijaya (2009) rasio ini digunakan untuk mengukur kemampuan manajemen bank dalam memperoleh keuntungan (laba) secara keseluruhan. Semakin besar ROA suatu bank, semakin besar pula tingkat keuntungan yang dicapai bank tersebut dan semakin baik pula posisi bank tersebut dari segi penggunaan aset. Rasio ini dapat dirumuskan sebagai berikut.

$$
\mathrm{ROA}=\frac{\text { lababersih }}{\text { totalaktiva }} \times 100 \%
$$

\section{c. Return on Equity (X2)}

Menurut Dendawijaya (2009) ROE adalah perbandingan antara laba bersih bank dengan modal sendiri. Return on Equity menggambarkan kemampuan modal sendiri untuk menghasilkan keuntungan bagi pemegang saham, karena dalam ROE yang digunakan sebagai pengukur efisiensi adalah besarnya laba bersih dari jumlah modal sendiri yang digunakan perusahaan. Jadi, ROE merupakan tingkat hasil pengembalian investasi bagi pemegang saham.Semakin besar rasio ini maka makin besar kenaikan laba bersih perusahaan yang bersangkutan. Rasio ini dapat dirumuskan sebagai berikut:

$$
\mathrm{ROE}=\frac{\text { lababersih }}{\text { modalsendiri }} \times 100 \%
$$

\section{d. Operating Profit Margin (X3)}

Menurut Harningsih (2012) merupakan rasio antara laba bersih operasi terhadap total penjualan. Laba bersih operasi sering disebut sebagai Earning Before Interest and Tax (EBIT) yang diperoleh dari gross profit dikurangi dengan biaya-biaya operasional perusahaan. Secara sistematis dapat dirumuskan sebagai berikut :

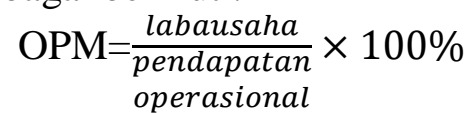

\section{e. Net Profit Margin (NPM)}

Menurut Dendawijaya (2009) net profit margin (NPM) adalah rasio yang menggambarkan tingkat keuntungan (laba) yang diperoleh bank dibandingkan denganpendapatan yang diterima dari kegiatan operasionalnya. Rasio ini dapat dirumuskan sebagai berikut. 


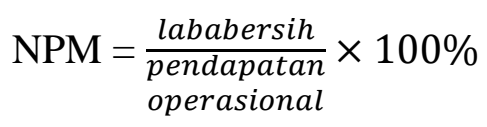

\section{f. Corporate Social Responsibility} (X5)

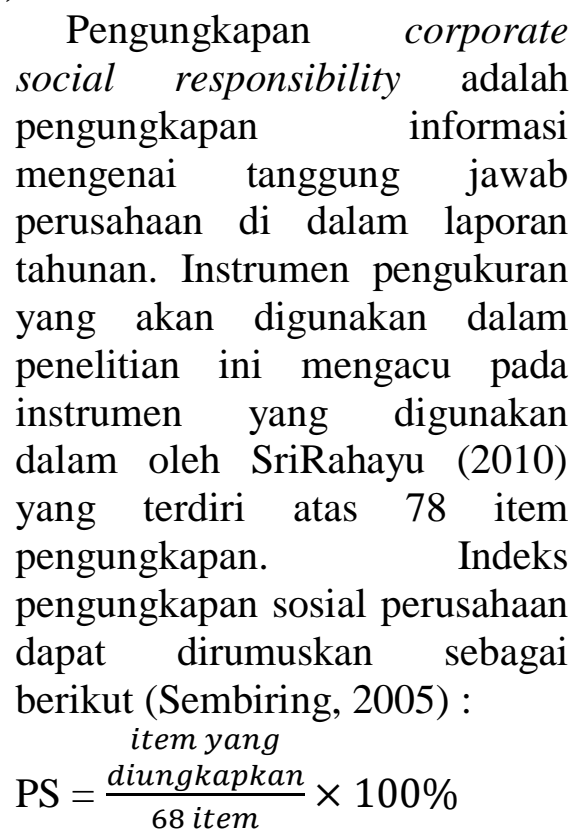

\section{Teknik Analisa Data}

\section{a. Analisa Statistik Deskriptif}

Uji statistik deskriptif berkenaan dengan bagaimana data dapat digambarkan/dideskripsikan, baik secara numerik misalnya menghitung rata-rata, standar deviasi atau secara grafis dalam bentuk tabel atau grafik.

\section{b. uji asumsi klasik}

Uji asumsi klasik digunakan untuk mendapatkan penduga koefisien regresi yang mempunyai error terkecil atau model regresi yangn dihasilkan adalah mempunyai sifat BLUE (Best Linier Unbiased Estimate) atau mempunyai sifat yang linier, tidak bias dan varian minimum. Adapun uji asumsi klasik adalah sebagai berikut:

\section{Uji Normalitas data}

Uji normalitas bertujuan untuk menguji apakah dalam model regresi variabel terikat dan variabel bebas keduanya mempunyai distribusi normal atau tidak.

\section{Uji Multikolinearitas}

Uji multikolinearitas bertujuan untuk melihat apakah model regresi yang digunakan atas korelasi antara variabel bebas. Model regresi yang baik seharusnya bebas multikolinearitas atau tidak terjadi kolerasi antara variabel independen. Syarat tidak terjadi Multikolinearitas adalah jika nilai korelasi antar variabel independen $<0,8$.

\section{3. uji heteroskedastisitas}

Uji heteroskedastisitas dilakukan dengan cara mellihat white heteroskedastisity test, dimana nilai probability $O b s * R$ squared $>$ 0,05 (alpha). Oleh karena itu nilai probability $O b s * R$-squared $>0,05$ maka tidak terjadi heteroskedastisitas.

\section{Uji Autokorelasi}

Uji autokorelasi yang digunakan untuk mendeteksi adanya gejala otokolerasi adalah Durbin-Waston Statistic Test. Jika Durbin-Wastonnya antara -2 sampai 2 berarti tidak terjadi autokorelasi (Gujarti, 2003).

\section{c. Analisis Regresi Berganda}

Analisis ini digunakan untuk mengetahui arah hubungan antara variabel independen dengan variabel dependen apakah masing-masing variabel independen berhubungan positif atau negatif untuk memprediksi nilai dari variabel dependen apabila nilai variabel independenmengalami kenaikan atau penurunan. Adapun variabel independen yang terdapat dalampenelitian ini antara lain ROA, ROE, OPM, NPM, dan CSR yang 
diuji pengaruhnya terhadapvariabel dependen nilai perusahaan yang diproksikan oleh PBV. Maka didapatkan rumuspersamaan regresi linier berganda sebagai berikut :

$Y=a+b_{1} X_{1}+b_{2} X_{2}+b_{3} X_{3}+b_{4} X_{4}+$ $\mathrm{b}_{5} \mathrm{X}_{5}+\mathrm{e}$

Keterangan :

$\begin{array}{ll}\mathrm{Y} & =\text { Nilai Perusahaan } \\ \mathrm{A} & =\text { Konstanta } \\ \mathrm{b}_{1}, \mathrm{~b}_{2}, . \mathrm{b} 5 & =\text { Koefisien Regresi } \\ \mathrm{ROA} & =\text { Return } \text { on asset } \\ \mathrm{ROE} & =\text { Retun } \text { on equity } \\ \mathrm{OPM} & =\text { Operating Profit } \\ \text { Margin } & \\ \mathrm{NPM} & =\text { Net profit Margin } \\ \mathrm{CSR} & =\text { Corporate social } \\ \text { responsibility } & \\ e & =\text { Error }\end{array}$

\section{a. Uji f (Silmutan)}

Pengujian ini dilakukan untuk mengetahui apakah semua variabel bebas yang digunakan dalam model regresi secara bersama-sama berpengaruh terhadap variabel terikat dan tingkat kesalahan atau probabilitas yang diinginkan $\mathrm{P}=5 \%$ (Ghozali, 2010) :

b. Uji t (Parsial)

Pengujian secara parsial, dilakukan uji-t untuk menguji pengaruh masing masing variabel bebas terhadap variabel terikat dan tingkat kesalahan atau probabilitas yang diinginkan $\mathrm{P}=5 \%$ (Ghozali, 2005) :

c. Koefisien Determinasi $\left(\mathbf{R}^{\mathbf{2}}\right)$

\section{Uji hipotesis}

\section{HASIL PENELITIAN DAN PEMBAHASAN}

\section{HASIL PENELITIAN}

\section{Statistik Deskriptif Variabel Penelitian}

Tabel 1

Hasil Uji Deskripsi Statistik Variabel Penelitian

\begin{tabular}{|l|l|l|l|l|c|}
\hline Variabel & $\mathrm{N}$ & Minimum & Maksimum & Mean & $\begin{array}{l}\text { Standar } \\
\text { Deviasi }\end{array}$ \\
\hline ROA & 64 & 0.090000 & 7.790000 & 1.459375 & 1.252863 \\
\hline ROE & 64 & 0.440000 & 82.62000 & 11.66188 & 12.90328 \\
\hline OPM & 64 & 1.580000 & 88.45000 & 20.12547 & 15.54836 \\
\hline NPM & 64 & 0.960000 & 85.91000 & 15.75422 & 14.52473 \\
\hline CSR & 64 & 1.470000 & 70.59000 & 18.24547 & 13.93944 \\
\hline PBV & 64 & 0.360000 & 4.630000 & 1.514844 & 0.892891 \\
\hline
\end{tabular}

Sumber : Data diolah, Lampiran 1

Pada tabel di atas menunjukan bahwa jumlah data yang digunakan dalam penelitian ini sebannyak 64 sampel data yang diambil dari laporan tahunan publikasi sektor perbankan yang tercatai di BEI periode 2014-2015.

Data rasio return on asset tertinggi (maksimum) adalah7.790000 dan yang terendah (minimum) adalah 0.090000 , kemudian rata-rata sebesar 1.459375 .
Sementara standar deviasi sebesar 1.252863 menunjukkan simpangan data yang relatif kecil, karena nilainya yang lebih kecil daripada nilai mean-nya yaitu sebesar $1.252863 .<1.459375$.

Data rasio return on equity tertinggi (maksimum) adalah 82.62000 dan yang terendah (minimun) adalah 0.440000 , kemudian rata-rata sebesar 11.66188. Sementara standar deviasi sebesar 12.90328 menunjukkan simpangan 
data yang relatif besar, karena nilainya yang lebih besar daripada nilai mean-nya yaitu sebesar $12.90328>11.66188$.

Data rasio operating profit margin tertinggi (maksimum) adalah 88.45000 dan yang terendah (minimun) adalah 1.580000 , kemudian rata-rata sebesar 20.12547. Sementara standar deviasi sebesar 15.54836 menunjukkan simpangan data yang relatif kecil, karena nilainya yang lebih kecil daripada nilai mean-nya yaitu sebesar $15.54836<20.12547$.

Data rasio net profit margin tertinggi (maksimum) adalah 85.91000 dan yang terendah (minimun) adalah 0.960000 , kemudian rata-rata sebesar 15.75422. Sementara standar deviasi sebesar 14.52473 menunjukkan simpangan data yang relatif kecil, karena nilainya yang lebih kecil daripada nilai mean-nya yaitu sebesar $14.52473<15.75422$.

Data rasio corporate social responsibility tertinggi (maksimum) adalah70.59000dan yang terendah (minimun) adalah 1.470000 , kemudian rata-rata sebesar 18.24547. Sementara standar deviasi sebesar 13.93944 menunjukkan simpangan data yang relatif kecil, karena nilainya yang lebih kecil daripada nilai mean-nya yaitu sebesar $13.93944<18.24547$.

Data rasio price to book value tertinggi (maksimum) adalah 4.630000 dan yang terendah (minimun) adalah 0.360000 , kemudian rata-rata sebesar 1.514844 . Sementara standar deviasi sebesar 0.892891menunjukkan simpangan data yang relatif kecil, karena nilainya yang lebih kecil daripada nilai mean-nya yaitu sebesar $0.892891<1.514844$.

\section{Uji Asumsi Klasik}

\section{a. Uji Normalitas data}

Tabel 2

Hasil Uji Normalitas Data

\begin{tabular}{|l|l|l|l|}
\hline \multicolumn{1}{|c|}{ Variabel } & $\mathrm{N}$ & $\begin{array}{c}\text { Jarque- } \\
\text { bera }\end{array}$ & probabilitas \\
\hline ROA & 64 & 5.964563 & 0.050677 \\
\hline ROE & 64 & 4.314295 & 0.115655 \\
\hline OPM & 64 & 2.821059 & 0.244014 \\
\hline NPM & 64 & 3.397978 & 0.182868 \\
\hline CSR & 64 & 2.097115 & 0.350443 \\
\hline PBV & 64 & 0.130154 & 0.936995 \\
\hline
\end{tabular}

Sumber: data diolah

Berdasarkan tabel 3 hasil dapat dilihat bahwa semua variabel baik dependen maupun independen telah terdistribusi normal. Karena nilai signifikan lebih dari 0,05 , sehingga data dalam penelitian ini dapat disimpulkan sudah berdistribusi normal memenuhi syarat model regresi karena sudah normal.

\section{b. Uji Multikolinearitas}

\begin{tabular}{|c|c|c|c|c|c|}
\hline & ROA & ROE & OPM & NPM & CSR \\
\hline ROA & 1.0000 & 0.3402 & 0.5667 & 0.7997 & 0.1403 \\
\hline ROE & 0.3402 & 1.0000 & 0.4042 & 0.2610 & -0.0551 \\
\hline OPM & 0.5667 & 0.4042 & 1.0000 & 0.6907 & 0.0519 \\
\hline NPM & 0.7997 & 0.2610 & 0.6907 & 1.0000 & 0.0923 \\
\hline CSR & 0.1403 & -0.0551 & 0.0519 & 0.0923 & 1.0000 \\
\hline \multicolumn{5}{|c}{ Tabel 3 }
\end{tabular}

\section{Hasil Uji Multikolinearitas Data}

Sumber: Data Diolah

Berdasarkan hasil olahan data pada Tabel 4 terlihat nilai kolerasi antara sesama variabel independen $<0,8$ sehingga dapat dikatakan bahwa sesama variabel independen tidak memiliki hubungan multikolinearitas.

\section{c. Uji Heteroskedastisitas}

\section{Tabel 4}

\section{Uji Heteroskedastisitas}

\begin{tabular}{|l|l|l|l|}
\hline F-statistic & 1.9024 & Prob. F(5,58) & 0.1078 \\
\hline Obs*R-squared & 9.0174 & Prob. Chi-Square(5) & 0.1084 \\
\hline
\end{tabular}


Sumber : Data diolah,

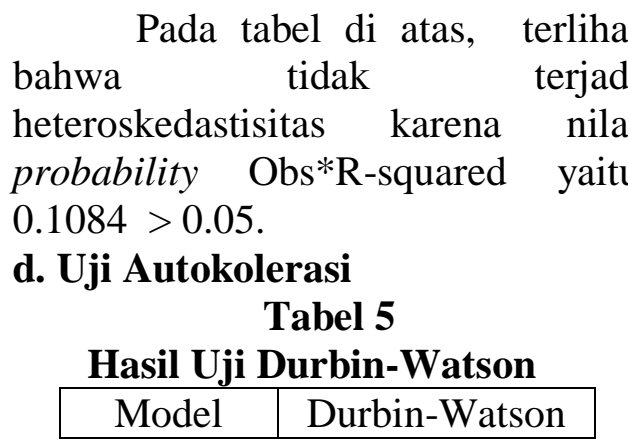

\section{\begin{tabular}{|c|c|}
\hline 1 & 1.956303 \\
\hline
\end{tabular}}

Sumber: Data Dioalah

Dari uji Darbin-Watson pada Tabel 5 terlihat bahwa tidak terjadi otokolrasi karena nilai DurbinWatson antara $-2<1.956303<2$.

\section{Analisis Regresi Linier Berganda}

\section{Tabel 6}

Hasil Uji Regresi Linier Berganda

\begin{tabular}{crrrr}
\multicolumn{1}{c}{ Variable } & Coefficient & Std. Error & t-Statistic & Prob. \\
\hline \hline C & 0.148791 & 0.277220 & 0.536725 & 0.5935 \\
ROA & -0.079829 & 0.122418 & -0.652108 & 0.5169 \\
ROE & 0.067618 & 0.068962 & 0.980510 & 0.3309 \\
OPM & -0.041914 & 0.133371 & -0.314266 & 0.7544 \\
NPM & 0.401216 & 0.140409 & 2.857485 & 0.0059 \\
CSR & 0.086958 & 0.072008 & 1.207602 & 0.2321 \\
\hline \hline R-squared & 0.296161 & Mean dependent var & 1.116763 \\
Adjusted R-squared & 0.235485 & S.D. dependent var & 0.235019 \\
S.E. of regression & 0.205492 & Akaike info criterion & -0.237757 \\
Sum squared resid & 2.449169 & Schwarz criterion & -0.035362 \\
Log likelihood & 13.60823 & Hannan-Quinn criter. & -0.158023 \\
F-statistic & 4.881043 & Durbin-Watson stat & 1.150269 \\
Prob(F-statistic) & 0.000855 & & &
\end{tabular}

\section{Sumber : Data Eviews}

Berdasarkan tabel 6, maka persamaan regresi linier berganda dengan 5 variabel independen sebagai berikut:

$\mathrm{Y}=\mathrm{a}+\mathrm{b}_{1} \mathrm{X} 1+\mathrm{b}_{2} \mathrm{X} 2+\mathrm{b}_{3} \mathrm{X} 3+\mathrm{b}_{4} \mathrm{X} 4$ $+b_{5} \mathrm{X} 5+\mathrm{e}$

$\mathrm{Y}=\mathrm{a}+\mathrm{b}_{1} \mathrm{ROA}+\mathrm{b}_{2} \mathrm{ROE}+\mathrm{b}_{3} \mathrm{OPM}$ $+\mathrm{b}_{4} \mathrm{NPM}+\mathrm{b}_{5} \mathrm{CSR}+\mathrm{e}$

Nilai Perusahaan $=0.148791-$ 0.079829 ROA +0.067618 ROE 0.041914 OPM $+0.401216 \mathrm{NPM}+$ $0.086958 \mathrm{CSR}+\mathrm{e}$

Persamaan regresi tersebut dapat dijelaskan sebagai berikut :
Konstanta sebesar 0.148791, artinya jika Return On Asset (ROA), Return On Equity (ROE), Operating Profit Margin (OPM), Net Profit Margin (NPM), dan Corporate Social Responsibility nilainya adalah 0 . Maka nilai perusahaan (PBV) nilainya akan mengalami peningkatan sebesar 0.148791 .

Koefisien regresi variabel Return On Asset (ROA) sebesar 0.079829 artinya jika variabel lain nilainya tetap dan ROA mengalami kenaikan sebesar $1 \%$. Maka nilai perusahaan mengalami penurunan 
sebesar -0.079829. Koefisien bernilai negatif artinya terjadi hubungan negatif antara ROA dengan nilai perusahaan, semakin besar ROA maka semakin menurun nilai perusahaan tersebut.

Koefisien regresi Return On Equity (ROE) sebesar 0.067618 artinya jika variabel independen lain nilainya tetap dan ROE mengalami kenaikan sebesar $1 \%$. Maka nilai perusahaan mengalami kenaikan sebesar 0.067618. Koefisien bernilai positif artinya terjadi hubungan positif antara ROE dengan nilai perusahaan, semakin besar ROE maka semakin meningkat nilai perusahaan tersebut.

Koefisien regresi Operating Profit Margin (OPM) sebesar 0.041914 artinya jika variabel independen lain nilainya tetap dan OPM mengalami kenaikan sebesar 1 $\%$. Maka nilai perusahaan mengalami penurunan sebesar 0.041914 . Koefisien bernilai negatif artinya terjadi hubungan negatif antara OPM dengan nilai perusahaan, semakin besar OPM maka semakin menurun nilai perusahaan tersebut.

Koefisien regresi Net Profit Margin(NPM) sebesar 0.401216 artinya jika variabel independen lain nilainya tetap dan NPM mengalami kenaikan sebesar $1 \%$. Maka nilai perusahaan mengalami kenaikan sebesar 0.401216. Koefisien bernilai positif artinya terjadi hubungan positif antara NPM dengan nilai perusahaan, semakin besar NPM maka semakin meningkat nilai perusahaan tersebut.

Koefisien regresi Corporate Social Responsibility (CSR) sebesar 0.086958 artinya jika variabel independen lain nilainya tetap dan ROE mengalami kenaikan sebesar 1 $\%$. Maka nilai perusahaan mengalami kenaikan sebesar 0.086958. Koefisien bernilai positif artinya terjadi hubungan positif antara CSR dengan nilai perusahaan, semakin besar CSR maka semakin meningkat nilai perusahaan tersebut.

\section{Uji Hipotesis}

a. Uji Koefisiensi Regresi Secara Simultan ( Uji f)

Dari Tabel 6 dihasilkan nilai FStatistic sebesar 4.881043 dengan nilai signifikansi probability FStatistic adalah 0.000855, tingkat probabilitasnnya lebih kecil dari 0,05 atau < 0,05. Hal tersebut mengidentifikasikan bahwa salah satu atau semua variabel independen ( ROA, ROE, OPM, NPM, dan CSR) berpengaruh secara signifikan terhadap variabel dependen (Nilai Perusahaan).

\section{b. Uji Koefisiensi Regresi Secara} Parsial (Uji t)

Dari hasil pengolahan data dihasilkan return on asset menunjukan $t_{\text {hitung }}-0.652108$ dengan nilai yang tidak signifikan 0.5169 lebih dari tingkat alpha 0.05 dan koefisien $\beta$ sebesar -0.079829 menunjukan nilai negatif. Hal ini berarti bahwa return on asset berpengaruh negatif dan tifak signifikan terhadap nilai perusahaan.

Untuk return on equity menunjukan $t_{\text {hitung }} 0.980510$ dengan nilai yang tidak signifikan 0.3309 tinggi dari tingkat alpha 0.05 dan koefisien $\beta$ sebesar 0.067618 menunjukan nilai positif. Hal ini berarti bahwa return on equity berpengaruh positif dan tidak signifikan terhadap nilai perusahaan.

Untuk operating profit margin menunjukan $t_{\text {hitung }}-0.314266$ dengan nilai yang tidak signifikan 0.7544 tinggi dari tingkat alpha 0.05 dan koefisien $\beta$ sebesar -0.041914 menunjukan nilai negatif. Hal ini 
berarti bahwa operating profit margin berpengaruh negatif dan tidak signifikan terhadap nilai perusahaan.

Untuk net profit margin menunjukan thitung 2.857485 dengan nilai yang signifikan 0.0059 kurang dari tingkat alpha 0.05 dan koefisien $\beta$ sebesar 0.401216 menunjukan nilai positif. Hal ini berarti bahwa net profit margin berpengaruh positif dan signifikan terhadap nilai perusahaan.

Untuk corporate social responsibility menunjukan $t_{\text {hitung }} 1.207602$ dengan nilai yang tidak signifikan 0.2321 tinggi dari tingkat alpha 0.05 dan koefisien $\beta$ sebesar 0.086958 menunjukan nilai positif. Hal ini berarti bahwa corporate social responsibility berpengaruh positif dan tidak signifikan terhadap nilai perusahaan.

\section{c. Koefisien Determinasi $\left(\mathbf{R}^{\mathbf{2}}\right)$}

Dari hasil pengolahan data ditemukan nilai $R$-squared 0.296161 ini berarti bahwa variabel bebas kinerja keuangan dan corporate social responsibility mempengaruhi nilai perusahaan sebesar $29,61 \%$ sedangkan sisanya $70,39 \%$ dipengaruhi oleh faktor lain.

\section{PEMBAHASAN}

\section{Pengaruh return on asset terhadap nilai perusahaan}

Dari hasil pengolahan data dihasilkan nilai koefisien regresi untuk variabel return on asset sebesar -0.079829 bertanda negatif dengan nilai probabilitas $0.5169>0.05$ yang berarti bahwa return on asset mempunyai pengaruh negatif dan tidak signifikan terhadap nilai perusahaan. Dengan demikian dapat disimpulkan hipotesis pertama ditolak.

Penelitian ini konsisten dengan hasil penelitian yang dilakukan oleh
Sasongko dan Wulandari (2006) yang menyatakan bahwa ROA secara parsial tidak berpengaruh terhadap harga saham. Artinya ROA tidak dapat digunakan untuk menentukan nilai perusahaan.

Penelitian ini sesuai dengan Natarsyah (2002) dalam Ulupui (2007) yang menemukan bahwa ROA tidak berpengaruh terhadap nilai perusahaan. Didalam penelitian (Perdana.,dkk 2007) juga ditemukan bahwa ROA tidak berpengaruh terhadap PBV. Hal ini menunjukkan bahwa ROA tidak berpengaruh terhadap nilai perusahaan.

2. Pengaruh return on equity terhadap nilai perusahaan

Dari hasil pengolahan data dihasilkan nilai koefisien regresi untuk variabel return on equity sebesar 0.067618 bertanda positif dengan nilai probabilitas $0.3309>$ 0.05 yang berarti bahwa return on equity mempunyai pengaruh positif dan tidak signifikan terhadap nilai perusahaan. Dengan demikian dapat disimpulkan hipotesis pertama ditolak.

Penelitian ini konsisten dengan hasil penelitian yang dilakukan oleh (Repi dkk., 2016) yang menyatakan bahwa ROE berpengaruh positif dan tidak signifikan terhadap nilai perusahaan. Menurut penelitian yang dilakukan oleh Ain (2013) ROE terbukti tidak berpengaruh terhadap nilai perusahaan, dengan sig. sebesar 0,372 untuk ROE. Hal ini terjadi karena adanya penurunan terhadap rata-rata ROE yang disebabkan banyaknya perusahaan sampel yang mengalami kerugian. Rahayu (2010) menyatakan bahwa ROE tidak berpengaruh signifikan terhadap nilai perusahaan, penyebabnya dimungkinkan karena buruknya 
kondisi perekonomian akibat adanya krisis global pada tahun 2008.

\section{Pengaruh operating profit} margin terhadap nilai perusahaan.

Dari hasil pengolahan data dihasilkan nilai koefisien regresi untuk variabel operating profit marginsebesar -0.041914 bertanda negatif dengan nilai probabilitas $0.7544>0.05$ yang berarti bahwa operating profit margin mempunyai pengaruh negatif dan tidak signifikan terhadap nilai perusahaan. Dengan demikian dapat disimpulkan hipotesis ketiga ditolak.

Penelitian ini konsisten dengan hasil penelitian yang dilakukan oleh Ardimas (2013) bahwa OPM tidak mempunyai pengaruh terhadap nilai perusahaan. Sejalan dengan penelitian ini, penelitian yang dilakukan oleh Joseph dkk., (2016) OPM tidak berpengaruh terhadap nilai perusahaan.

\section{Pengaruh net profit margin terhadap nilai perusahaan}

Dari hasil pengolahan data dihasilkan nilai koefisien regresi untuk variabel net profit margin sebesar 0.401216 bertanda positif dengan nilai probabilitas 0.0059 < 0.05 yang berarti bahwa net profit margin mempunyai pengaruh positif dan signifikan terhadap nilai perusahaan. Dengan demikian dapat disimpulkan hipotesis keempat diterima.

Penelitian ini konsisten dengan hasil penelitian yang dilakukan oleh Riana (2016) bahwa NPM mempunyai pengaruh yang signifikan terhadap nilai perusahaan (Tobin's Q), hasil uji t menunjukkan hanya variabel NPM yang mempunyai pengaruh signifikan dan berhubungan positif terhadap nilai perusahaan. Penelitian ini juga didukung oleh penelitian yang dilakukan oleh Batubara (2015) dan munawaroh (2014) bahwa NPM mempunyai pengaruh yang positif signifikan terhadap nilai perusahaan (Tobin'sQ). Dimana menunjukkan bahwa semakin tinggi laba bersih perusahaan maka semakin tinggi nilai perusahaannya.

5. Pengaruh $\begin{aligned} & \text { corporate } \\ & \text { responsibility } \\ & \text { terhadap } \\ & \text { perusahaan } \\ & \text { nari hasilai }\end{aligned}$
pengolahan data
dihasilkan nilai koefisien regresi untuk variabel corporate social responsibility sebesar 0.086958 bertanda positif dengan nilai probabilitas $0.2321>0.05$ yang berarti bahwa CSR mempunyai pengaruh positif dan tidak signifikan terhadap nilai perusahaan. Dengan demikian dapat disimpulkan hipotesis kelima ditolak.

Penelitian ini konsisten dengan hasil penelitian yang dilakukan olehJoseph dkk., (2016) Nilai signifikansi yang lebih besar dari 0,05 tersebut menandakan bahwa pengungkapan CSR tidak mempengaruhi secara signifikan terhadap nilai perusahaan. Hal ini menunjukkan bahwa investor tidak merespon atas pengungkapan CSR yang telah dilakukan oleh perusahaan. Penelitian ini juga didukung oleh penelitian yang dilakukan oleh Ardimas (2010) yang mengemukakan hasil bahwa pengungkapan CSR tidak berpengaruh secara signifikan terhadap nilai perusahaan.

\section{KESIMPULAN}

1. Variabel kinerja keuangan yang diukur dengan return on assets (ROA), return on equity(ROE), operating profit margin(OPM) tidak mempunyai pengaruh signifikan terhadap nilai perusahaan. Sedangkan variabel 
kinerja keuangan lainya, yaitu net profit margin (NPM) mempunyai pengaruh secara signifikan terhadap nilai perusahaan pada perusahaan sektor perbankan yang go public di Bursa Efek Indonesia.

2. Variabel corporate social responsibility (CSR) tidak mempunyai pengaruh secara signifikan terhadap nilai perusahaan pada perusahaan sektor perbankan yang go public di Bursa Efek Indonesia.

\section{SARAN}

Berdasarkan hasil dari penelitian dan kesimpulan di atas diharapkan melakukan penelitian lanjutan dengan memperbanyak jumlah observasi agar memperoleh hasil yang lebih akurat misalnya : Penelitian selanjutnya diharapkan dapat menggunakan periode penelitian yang lebih panjang dengan tujuan untuk memperoleh hasil yang lebih baik. Penelitian selanjutnya diharapkan menggunakan penerapan good corporate governance(GCG) selain corporate social responsibility (CSR) sebagai variabel dependen dalam pengaruhnya terhadap nilai perusahaan. Penelitian selanjutnya diharapkan menggunakan rasio keuangan perusahaan yang berbeda, yang belum, yang belum dimasukkan dalam model penelitian ini. Karena masih terdapat rasio keuangan yang mungkin juga berpengaruh terhadap nilai perusahaan selain return on asset(ROA), return on equity (ROE), operating profit margin (OPM), dan net profit magin (NPM).

DAFTAR PUSTAKA

Rahayu, Sri. 2010. Pengaruh Kinerja Keuangan Terhadap Nilai Perusahaan dengan Pengungkapan Corporate Social Responsibility dan
Good Corporate Governance Sebagai Variabel Pemoderasi. Unpublished Skripsi Fakultas Ekonomi. Universitas Diponogoro. Semarang.

Zuredah, Isnaeni Ken. 2010. Pengaruh Kinerja Keuangan Terhadap Nilai Perusahaan Dengan Pengungkapan Corporate Social Responsibility Sebagai Variabel Pemoderasi.Skripsi Fakultas Ekonomi. Universitas Pembangunan Nasional. Jakarta

Aurellya.2012. "Faktor-Faktor Yang Mempengaruhi Nilai

Perusahaan Pada Industri Pertambangan Di Bursa Efek Indonesia. Vol . 14, No 2.

Munawaroh, Aisyatul. 2014 "Pengaruh

Profi Tabilitas Terhadap

Nilai Perusahaan Dengan

Corporate Social

Responsibilty Sebagai

Variabel Moderating" Jurnal Ilmu \& Riset Akuntansi Vol.

3 No. 4.

Joseph, natalia dkk. 2016. "Pengaruh

Kinerja Keuangan Dan

Corporate Social

Responsibility (Csr)

Terhadap Nilai Perusahaan

Manufaktur Yang Terdaftar

Di Bursa Efek Indonesia"

Fakultas Ekonomi dan Bisnis

Jurusan Akuntansi

Universitas Sam Ratulangi.

Riana, Lutcy. 2016. "Analisis Pengaruh Kinerja Keuangan Dan Corporate Social Responsibility Terhadap Nilai Perusahaan"

Ain, Syarifa dan Setijaningsih, Herlin. 2012. "Pengaruh Return On Asset (Roa) Return On Equity (Roe) Dan 
Kepemilikan Manajerial

Terhadap Nilai Perusahaan (Studi Empiris Pada

Perusahaan Manufaktur Di

Bursa Efek Indonesia (Bei)

Periode 2009-2011)”.

Universitas Bina Nusantara,

Jl. Kebon Jeruk Raya No. 27, Jakarta Barat 11530.

Repi, Switli dkk. 2016. "Faktor-

Faktor Yang Mempengaruhi

Nilai Perusahaan Subsektor

Perbankan Pada Bei Dalam

Menghadapi MEA". Fakultas

EkonomI Dan Bisnis Jurusan

Manajemen Universitas Sam

Ratulangi Manad. Jurnal

Emba.Vol.4 No.1

Ardimas, Wahyu. 2011. "Pengaruh

Kinerja Keuangan Dan

Corporate Social

Responsibility Terhadap Nilai

Perusahaan Pada

Perusahaan Sektor

Perbankan Di Bursa Efek

Indonesia. Jurusan

Manajemen Fakultas

Ekonomi, Universitas

Gunadarma.

Amri, Chairul. 2011.Analisis

Pengaruh Kinerja Keuangan,

Good Corporate

Governance dan Corporate

Social Responsibility

Terhadap Nilai

Perusahaan. Skripsi Fakultas

Ekonomi. Universitas

Gunadarma. Depok.

Chandra, Eva T.M. 2010. Pengaruh

Kinerja Keuangan

Terhadap Nilai Perusahaan

Dengan Pengungkapan

Corporate Social

Responsibility Sebagai

Variabel Pemoderasi Pada

Perusahaan Manufaktur

Yang Terdaftar Di Bursa

Efek Indonesia. Skripsi
Fakultas Ekonomi.

Universitas Sumatera Utara. Medan.

Dendawijaya, Lukman. 2009.

Manajemen Perbankan.

Ghalia Indonesia.

Jakarta.

Hadya, R. (2013). Pengaruh Harga dan Risiko Saham Terhadap

Likuiditas Saham Pada

Perusahaan-Perusahaan Yang

Terdaftar Di Bursa Efek

Indonesia. Jurnal KBP, 1(2),

208-231.

Handoko, Yuanita. 2010. Pengaruh

Kinerja Keuangan Terhadap

Nilai Perusahaan Dengan

Pengungkapan Corporate

Social Responsibility

dan Good Corporate Social

Responsibility Sebagai

Variabel Pemoderasi.

Skripsi Fakultas Ekonomi.

Universitas Gunadarma.

Depok.

Hermawati, Angra. 2010. Pengaruh

Kinerja Keuangan Terhadap

Nilai PerusahaanDengan

Pengungkapan Corporate

Social Responsibility

Dan Struktur Kepemilikan

Sebagai Variabel

Pemoderasi.Skripsi

Fakultas Ekonomi.

Universitas Gunadarma.

Depok.

Kusumadilaga, Rimba. 2010.

Pengaruh Corporate Social

Responsibility Terhadap

Nilai Perusahaan Dengan

Profitabilitas Sebagai

Variabel Moderating

(Studi Empiris pada

Perusahaan Manufaktur

yang terdaftar di Bursa

Efek Indonesia). Skripsi

Fakultas Ekonomi. 
Universitas Dipenogoro. Semarang

Nurlela, Rika dan Islahudin. 2008. Pengaruh Corporate Social Responsibility terhadap Nilai Perusahaan dengan Prosentase Kepemilikan Manajemen sebagai Variabel Moderating. Simposium Nasional Akuntansi XI. Pontianak.

Ulupui, I. G. K. A. 2007. Analisis Pengaruh Rasio Likuiditas, Leverage, Aktivitas, dan Profitabilitas terhadap Return Saham.Jurnal Akuntansi dan Bisnis Vol.2.

Veronica, Thedora Martina dan Wardoyo.2013. Pengaruh Kinerja Keuangan, Good Corporate Governance dan Corporate Social Responsibility terhadap Nilai Perusahaan. Jurnal Dinamika ManajemenVol. 4, No. 2, 2013, pp: 132-149.

Yuniasih, Ni Wayan dan Made Gede Wirakusuma. 2007. Pengaruh Kinerja Keungan Terhadap Nilai Perusahaan Dengan Pengungkapan Corporate Social Responsibility dan Good Corporate Governance Sebagai Variabel Pemoderasi. Skripsi Fakultas Ekonomi. Universitas Udayana. Denpasar.

Sugiono, 2008, statistika untuk penelitian, CV Alvabeta. Bandung

Suhartono, \& Yusra, I. (2019). Analisis perbandingan kinerja keuangan bank konvensional dengan bank syariah yang terdaftar di BEI. INA-Rxiv, 1-9.

Yusra, I. (2016). Kemampuan Rasio Likuiditas dan Solvabilitas dalam Memprediksi Laba
Perusahaan: Studi Empiris pada Perusahaan Telekomunikasi yang Terdaftar di Bursa Efek Indonesia. Jurnal Benefita, 1(1), 33-42.

https://doi.org/http://dx.doi.org/ 10.22216/jbe.v1i1.878

Yusra, I., Hadya, R., \& Fernandes, J. (2017). Likuiditas , financial leverage, dan prediktabilitas beta: pendekatan Fowler and Rorke sebagai metode koreksi Beta. Jurnal Benefita, 2(1), 8191. 